
КРИТИЧНЕ МИСЛЕННЯ ЯК НЕОБХІДНИЙ СКЛАДНИК МЕДІАОСВІТИ
МАЙБУТНЬОГО ВЧИТЕЛЯ ПОЧАТКОВИХ КЛАСІВ

\title{
CRITICAL THINKING AS A NECESSARY COMPONENT OF THE MEDIA EDUCATION OF THE FUTURE TEACHER OF PRIMARY SCHOOL
}

У статті розглянуто особливості форму-
вання критичного мислення як складової
частини медіаосвіти майбутніх учителів
початкових класів у сучасному інформа-
ційному суспільстві. Визначено ключові
аспекти критичного мислення та його
характерні особливості. Критичне мис-
лення передбачає здатність самостійно
аргументувати причину загальноприйня-
тих стандартів або відкладати їх, вису-
ваючи суттєві і переконливі докази; не
вимагає дотримання алгоритмів чи інших
механічних процедур.

Виділено та охарактеризовано два компоненти критичного мислення: змістовний та операційний. Описано якості (готовність до планування, гнучкість, наполегливість, готовність виправляти свої помилки, усвідомлення, позитивна установка на критичне мислення) та дослідницькі навички (визначати, спостерігати, описувати, асоціювати, порівнювати, прогнозувати, узагальнювати, застосовувати), що властиві людині, яка володіє критичним мисленням. Швидкі темпи розвитку інформаційно-комунікаційних технологій та системи мас-медіа вносять принципові зміни у загальну освіту та потребують модернізації фрахової підготовки майбутніх учителів початкових класів.

Розкрито у загальному контексті необхідність орормування та розвитку критичного мислення як складової частини медіаосвіти в освітньо-виховному процесі закладів вищої освіти. У рамках медіаосвіти виокремлено п'ять ключових складників критичного мислення: допитливість і бажання досліджувати, постійне занурення у процес дослідження, базове скептичне ставлення, поціновування аргументації, гнучкість і неупередженість.

Отже, критичне мислення $\epsilon$ базовою компетенцією для фрормування та розвитку особистості майбутнього вчителя початкової школи. Педагогічна підготовка у контексті медіаосвіти включає в себе формування основ критичного мислення: навички інтерпретації фрактів і різних джерел інорормації: знайомство із загальними принципами пошуку інформації, уміння розпізнавати свідомі спотворення інфрормації, вміння доповнювати інфрормацію, якої бракує.

Перспективу подальших досліджень убачаємо в удосконаленні методичного складника медіаосвіти майбутніх учителів початкових класів у контексті формування та розвитку критичного мислення.

Ключові слова: критичне мислення, медіаосвіта, медіаграмотність, майбутній учитель початкових класів, молодший школяр.

In the article we consider the peculiarities of the formation of critical thinking as a component of the media education of future teacher of primary school in the modern information society.

We have identified key aspects of critical thinking and its characteristic features. Critical thinking involves the ability to independently argue the reason for generally accepted standards or postpone them, putting forward substantial and convincing evidence; it does not require compliance with algorithms or other mechanical procedures.

We describe the qualities (readiness for planning, flexibility, perseverance, willingness to correct our mistakes, awareness, positive installation on critical thinking) and research skills (identify, observe, describe, associate, compare, predict, generalize, apply) inherent in a person who has critical thinking . The rapid pace of development of information and communication technologies and the mass media system make fundamental changes in general education and require modernization of professional training of future teachers of primary school.

In the general we revealed to need to form and develop critical thinking as a component of media education in the educational process of higher education institutions. Within the framework of media education, five key components of critical thinking are distinguished: curiosity and desire to explore, constant immersion in the research process, basic skepticism, value of argumentation, flexibility and impartiality.

Therefore, critical thinking is the basic competence for the formation and development of the personality of the future teacher of primary school. Pedagogical training in the context of media education includes the formation of the basics of critical thinking: the skills of interpreting facts and various sources of information: familiarization with the general principles of information search, the ability to recognize conscious distortions of information, the ability to supplement the missing information.

We see the prospects for further research in the improved methodological component of the media education of future teachers of primary school in the context of the formation and development of critical thinking.

Key words: critical thinking, media education, media literacy, future teacher of primary school, junior student
Постановка проблеми в загальному вигляді. Швидкі темпи розвитку сучасного інфрормаційного суспільства зумовили потребу у фрормуванні у підростаючого покоління низки ключових компетентностей. У концепції Нової української школи виокремлюють 10 ключових компетентностей (спілкування державною (і рідною у разі відмінності) мовою, спілкування іноземними мовами, математична компетентність, інфрормаційно-цифрова компетентність, уміння вчитися впродовж життя тощо). Одним зі спільних для всіх компетентностей є вміння критично мислити [3, с. 15-16].

Критичне мислення $є$ ключовим поняттям медіаосвіти; комплекс усвідомлених дій та навичок, які використовуються особистістю для аналізу певної інформації. 
Процес формування вміння критичного мислення відбувається постійно, проте найсприятливішим періодом уважають час навчання в школі, зокрема у початкових класах, тому важливим завданням майбутніх учителів початкових класів $€$ розвиток власного критичного мислення, тобто вмінь сприймати, критично аналізувати, інтерпретувати та узагальнювати отриману інформацію.

Аналіз останніх досліджень і публікацій. Вивчення особливостей фрормування та розвитку критичного мислення як складової частини медіаосвіти є предметом дослідження багатьох провідних науковців. Теоретичний аспект цієї проблеми розкрито у працях як зарубіжних (К. Безелгет, Дж. Браун, К. Ворсноп, І. Жилавська, Р. К'юбі, М. Маклюен, Л. Мастерман, Дж. Поттер, Ф. Рогоу, Ю. Усов, І. Фатєєва, О. Федоров, С. Шейбе), так і вітчизняних (В. Іванов, О. Баришполець, Л. Найдьонова, Г. Онкович, Б. Потятиник, А. Сулім та ін.) дослідників.

Виділення не вирішених раніше частин загальної проблеми. Стрімкий розвиток медіазасобів у сучасному інформаційному суспільстві потребує вмілого та безпечного користування ними підростаючим поколінням, тому стаття присвячується розгляду характерних особливостей критичного мислення як невід'ємної складової частини медіаосвіти майбутніх учителів початкових класів.

Мета статті. Мета статті - виокремити характерні особливості формування та розвитку критичного мислення майбутніх учителів початкових класів у процесі фрахової підготовки.

Виклад основного матеріалу. Важливо розуміти, що сорормувати в учнів початкової школи здатність критично оцінювати життєві події та ситуації може лише вчитель або ж майбутній учитель, у якого вже сорормовано критичне мислення, тому для фрормування та розвитку критичного мислення у майбутніх учителів початкових класів необхідне чітке розуміння його особливостей.

Критичне мислення (синонім - нестандартне мислення) - здатність індивіда самостійно аргументувати причину загальноприйнятих стандартів або відкладати їх, висуваючи суттєві і переконливі докази [1, с. 154].

Визначають такі ключові аспекти критичного мислення [5, с. 5-8]:

По-перше, критичне мислення - самостійне і має індивідуальний характер.

По-друге, інформацію слід розглядати як відправну, але не кінцеву точку критичного мислення. Знання створює базу і дає мотивацію, без якої людина не здатна критично мислити. Для того щоб створити вагому думку, треба опрацювати багато інформації.

По-третє, критичне мислення виникає зі з'ясування та формулювання проблем, із поста- новки питань, які слід вирішувати. Для процесу пізнання характерне намагання суб'єкта розв'язувати проблеми і відповідати на питання, які з'являються поряд із його власними потребами й інтересами. Критичне мислення як особливий вид розумової діяльності дає людині можливість робити об'єктивні оцінки стосовно пропонованої моделі поведінки, думки чи точки зору.

По-четверте, критичне мислення передбачає переконливу аргументацію. Критично мисляча особистість намагається знайти власне розв'язання проблеми і вибирає для такого рішення ґрунтовні докази, а також розуміє, що можливі ще інші шляхи вирішення поставленої проблеми, і здатна визначити логічність та раціональність власного рішення. Аргументація міцнішає, коли беруться до уваги всі можливі контраргументи, які або сприймаються за істинні, або піддаються спростуванню. Визнання інших поглядів і точок зору завжди підсилює аргументацію.

По-п'яте, критичне мислення - це соціальне мислення. Кожна думка апробується за умови її обговорення у соціумі. Обмінюючись думками, ми дискутуємо, сперечаємося, осмислюємо та уточнюємо свою позицію.

Критичне мислення сорормоване двома компонентами: змістовним та операційним. До змістовного складника критичного мислення належать:

1) загальні методологічні принципи - переконання у важливості самокорегування дослідницького методу, увага до дослідницької процедури, готовність критично ставитися до себе, до інших, урахування усіх точок зору;

2) стратегії - розділити основну проблему на частини; розв'язати простіші завдання, які відображають окремі аспекти загальної проблеми; подати проблему різними способами; розглянути окремі випадки в межах проблеми; здійснити аналіз мети і засобів.

Операційну компонентну визначають уміння контролювати розумову діяльність та її самовдосконалення: 1) уміти визначити проблему та розуміти зв'язок між суперечностями; 2) здійснювати доведення, тобто добирати прийнятні докази; 3) відшуковувати контраргументи; 4) враховувати факти, які суперечать власним думкам; 5) уміти обґрунтовувати; 6) оцінювати, щоб вибрати один із варіантів, розуміти обмеження, які можуть накладатися на висновки; 7) уміти спростовувати фальсифрікацію; 8) здійснювати узагальнення; 9) висувати припущення; 10) робити висновки [6, с. 38-39].

Головними характеристиками критичного мислення $є$ здатність самостійно аналізувати інорормацію, з'ясовувати її суть, зіставляти з іншими відомостями і робити висновки; переглядати власну позицію, якщо вона не витримує критики; уміти помічати помилки, суперечності й спотво- 
рення в аргументації опонента та в іншій інорормації; навички розпізнавати пропаганду як цілеспрямоване прагнення певних соціальних груп чи лідерів впливати на масову свідомість; уміння оцінювати суспільно-політичні явища й процеси, дії та вчинки державних і політичних лідерів, конкретних осіб із позицій загальнолюдської моралі; володіти розумною часткою сумнівів і скепсису; намагання шукати оптимальні рішення, дії, висновки в конкретних ситуаціях; мужність, принциповість, сміливість у відстоюванні власних позицій, поглядів, віри; відкритість для інших поглядів, цінностей і позицій, повага до їхнього різноманіття [2, с. 75-76].

Своєю чергою, Д. Халперн виокремлює якості, які властиві людині, яка володіє критичним мисленням [9]:

- готовність до планування (уміння стримувати свою імпульсивність і складати план своїх дій);

- гнучкість (відсутність ригідності і догматизму в мисленні, готовність розглядати нов варіанти, прагнення прояснити складні для себе питання, змінювати свою точку зору);

- наполегливість (готовність взятися за вирішення завдання і не відступати, допоки воно не буде вирішено);

- готовність виправляти свої помилки (уміння визнавати, а не виправдовувати свої помилки, вчитися на них, уміння бути відкритим до критики оточуючих);

- усвідомлення (спостереження за власними розумовими діями, тобто, по суті, рефлексивний самоконтроль);

- позитивна установка на критичне мислення (активне прагнення навчитися мислити критично).

У процесі критичного мислення застосовують такі дослідницькі навички: визначати (демонструвати або доводити існування об'єкта, розпізнавати його), спостерігати (розпізнавати ознаки й властивості об'єкта), описувати (з'ясовувати, як виглядає об'єкт), асоціювати (встановлювати зв'язок між об'єктами і зіставляти їх за їх взаємодією), порівнювати (визначати подібності й відмінності між об'єктами, оцінювати об'єкти), прогнозувати (робити припущення щодо майбутнього), узагальнювати (робити висновки на базі існуючих відомостей), застосовувати (використовувати критичне мислення $з$ практичною користю).

Критичне мислення може мати також негативний аспект через неправильні уявлення як результат своєї «критичності». Водночас воно не передбачає неприйняття інших суджень чи тотальну критику всієї інфрормації, що надходить. Перш за все це різнобічний підхід до досліджуваної проблеми майбутнім учителем початкових класів, щоб школяр міг прийняти своє виважене, ретельно обдумане та обґрунтоване рішення. Орієнтація шкільних уроків і всієї освітньої програми на розвиток критичного мислення передбачає те, що знання не подаються у готовому вигляді; інорормація, яку молодші школярі отримують із різних джерел, не приймається одразу на віру і не може бути незаперечним фрактом. Вона передбачає ретельне дослідження та обмірковування, і, як результат, кожен школяр шукає і фрормує свою думку в рамках освітнього процесу. Тобто критичному мисленню притаманні усвідомлені дії та навички, завдяки яким можна оцінювати отриману інорормацію (текстову, звукову, візуальну).

Ці особистісні якості та дослідницькі навички притаманні також сучасним учителям та $€$ невід'ємним складником їхньої професійної підготовки в університеті, зокрема під час вивчення курсу медіаосвіти. Деякі науковці, трактуючи поняття «медіаосвіта», ототожнюють його 3 критичним мисленням. Зокрема, С. вон Файлітзен уважає, що медіаосвіта означає критичне мислення, суттєвим елементом якого є створення власної медіапродукції [8]; О. Федоров зазначає, що метою медіаосвіти як процесу розвитку особистості за допомогою і на матеріалі засобів масової інформації (мас-медіа) є фрормування критичного мислення, уміння певною мірою сприймати, інтерпретувати, аналізувати й оцінювати медіатексти, навчати різним фрормам самовираження за допомогою медіатехніки [7]; А. Литвин також стверджує, що кінцевою метою медіаосвіти є здатність до критичного сприйняття медіаповідомлень [4].

У рамках медіаосвіти варто виокремити п'ять ключових складників критичного мислення:

1. Допитливість i бажання досліджувати. Носії критичного мислення хочуть дізнаватися більше, вони відкидають надмірні спрощення та збирають усі відомості перед тим, як робити висновки.

2. Постійне занурення у процес дослідження. Носії критичного мислення добирають, аналізують та оцінюють інформацію, що дає їм змогу робити висновки, відповідно до яких скеровується поведінка або обґрунтовуються рішення. Вони досліджують питання, з якими вони погоджуються, так само ретельно, як і ті, що викликають у них підозри.

3. Базове скептичне ставлення. Ті, хто мислить критично, завжди відшукують відомості, припущення, мотиви у задекларованих заявах.

4. Поціновування аргументації. Носії критичного мислення здатні розрізняти фракти та думки. Вони вміють шукати та оцінювати ймовірні докази, використовувати логіку, щоб робити висновки.

5. Гнучкість і неупередженість. Носії критичного мислення свідомі власних упереджень і вміють піддавати їх сумніву, охоче змінюють власні думки, якщо з'являються відповідні фрактичні дані, 
погоджуються 3 існуванням невизначеності та непевності у світі й регулярно отримують інфрормацію з різних джерел [10, с. 66].

Мета навчання медіаграмотності як складової частини медіаосвіти та критичного мислення учнів початкових класів - формування практичних навичок із розуміння, аналізу й оцінювання змісту медіа, здатності створити власний медіапродукт і оцінити власну медіаактивність. Звідси, головною метою сучасного вчителя $€$ навчити молодших школярів критично ставитися до інформаційних повідомлень, фрормувати здатність розуміти реальність.

Критичне мислення є важливим і для майбутніх учителів початкової школи, оскільки допомагає вирішувати такі завдання під час організації освітнього процесу, як відбір змісту начального матеріалу, вибір фрорм, методів та прийомів організації навчально-виховної діяльності молодших школярів. Відбираючи матеріали для побудови уроків, майбутні вчителі застосовують різні елементи критичного обмірковування 3 погляду його актуальності, практичної значущості, зв'язку з іншими дисциплінами та достовірності. Саме завдяки критичному мисленню викладача, який оцінює матеріал і вибудовує пізнавальну діяльність студента в рамках курсу медіаосвіти з використанням різних освітніх технологій і методик, традиційний процес пізнання студента набуває індивідуальності, стає осмисленим, безперервним і продуктивним.

Висновки. Потреба у срормуванні критичного мислення молодших школярів є провідною у сучасному інорормаційному суспільстві. Критичне мислення допомагає учням аналізувати отриману інформацію та обґрунтовувати свою думку, висувати власні припущення, розрізняти фракти та сумнівні гіпотези тощо.

Навичка критичного мислення має бути сорормована безпосередньо у вчителів початкової школи, оскільки вона опосередковано впливає на якість їхньої професійної діяльності.

Із сказаного вище можна зробити висновок, що критичне мислення є необхідною складовою частиною медіаосвіти майбутніх учителів початкової школи у процесі фрахової підготовки.

\section{БІБЛІОГРАФІЧНИЙ СПИСОК:}

1. Баришполець О. Український словник медіакультури. Київ : Міленіум, 2014. 196 с.

2. Вчимося бути медіаграмотним / за заг. ред. М. Масютіної. Бердянськ : Колібрі ; Запоріжжя : Дике поле, 2016. 200 c.

3. Концепція нової української школи / М-во освіти та науки України. URL: https://www.kmu.gov.ua/ storage/app/media/reforms/ukrainska-shkolacompressed.pdf (дата звернення: 02.07.2021).

4. Литвин А. Завдання медіаосвіти в контексті підвищення якості професійної підготовки. URL: http:// lib.iitta.gov.ua (дата звернення: 03.07.2021).

5. Терно С. Методика розвитку критичного мислення школярів у процесі навчання історії. Запоріжжя : Запорізький національний університет, 2012. $70 \mathrm{c}$.

6. Терно С. Теорія розвитку критичного мислення (на прикладі навчання історії). Запоріжжя : Запорізький національний університет, 2011. 105 с.

7. Федоров А. Словарь терминов по медиаобразованию, медиапедагогике, медиаграмотности, медиакомпетентности. Таганрог : Таганрог. гос. пед. ун-т, 2010. 64 с.

8. Feilitzen C. von. Media Education, Children's Participation and Democracy. Goteborg : UNESCO \& NORDICOM, 1994. P. 24-26.

9. Халперн Д. Психология критического мышления / пер. с англ. Н. Мальгиной, С. Рысева, Л. Царук. Санкт-Петербург : Питер, 2000. 512 с.

10. Шейбе С., Рогоу Ф. Медіаграмотність: критичне мислення у мультимедійному світі / пер. 3 англ. С. Дьома ; за заг. ред. В. Іванова, О. Волошенюк. Київ : Центр Вільної преси, Академія української преси, 2017. 319 с. 